It will be seen from the above that the alkaliinsoluble fraction (containing cannabinol, etc. (?)) was found to be the pharmacologically active fraction under the conditions of our experiments. The alkalisoluble fractions even in three times higher dosage and in the same experimental conditions did not reveal any narcotic activity. This raises the question as to whether 'cannabinol' could be considered as a physiologically inactive phenol, as has been indicated in previous reports ${ }^{8,13}$.

Unless further experimental work is done with pure cannabinol, it seems too premature to hazard any definite statement regarding its physiological potency. It may, however, be presumed from the biological assay results on the alkali-insoluble fraction of charas that possibly cannabinol may be the precursor. of the true active ingredient, the phenol being broken down in the system to some other derivative possessing the ethenoid linkage but with more intense physiological activity. The synthesis by Adams and his co-workers ${ }^{12}$ of some tetra-hydro-cannabinols possessing strong hashish activity also lends support to this supposition.

Our thanks are due to Sir R. N. Chopra and Dr. H. B. Dunnicliff for their continued interest in this work.

Smith, Pharm. J., 6, 70 (1846)

2 Wood, Spivey and Easterfleld, J. Chem. Soc., 539 (1896).

- Wood, Spivey and Easterfield, J. Chem. Soc., 20 (1899).

- Frenkel, Arch. exp, Path. Pharm., 49, 266 (1903).

${ }^{5}$ Czerkis, Ann., 351, 467 (1907).

- Casparis, Pharm. Helv. Acta, I, 210 (1926).

'Bergel, Ann., 482, 55 (1930).

- Cahn, J. Chem. Soc., 986 (1930)

- Cahn, J. Chem. Soc., 1400 (1933).

10 Myttenaere, F., League of Nations Documents O.C. 1724. J. Pharm. belg., 20, 341-4, 357-9; 683-6, 702-7; 723-8 (1938); 22, 163-8 $(1940)$

1 Jacob and Todd, NATURE, 145, 350 (1940).

12 Adams, Hunt and Clark, J. Amer. Chem. Soc., 62, 196 (1940).

1s Marshall, Lancet, I, 235 (1897).

"Work, Bergel and Todd, Biochem. J., 33, Part 1, 123 (1939).

1s Beam, Wellcome Trop. Res. Lab., 4th Rept. $(B), 25$.

16 'Vanillin test', cited by Fulton, C. C., Ind. Eng. Chem., 14, 407 (1942).

17 Ghosh and Bhattacharji, Analyst, 60, 313 (1935).

is Gayer, Arch. exp. Path. Pharm., 129, 312 (1928).

\section{FISHERIES RESEARCH IN AUSTRALIA}

$\mathrm{V}$

ALUABLE research in biological fishery problems is being carried out by the Council for Scientific and Industrial Research, Commonwealth of Australia. The primary objective of the current investigation* is to obtain a well-founded estimate of the pelagic fishery resources of Australian waters, and in this is included oceanographical work concerned with changes in currents and water conditions generally, together with their effect on the amount and distribution of plankton. Roughly speaking, the course of the fisheries varies according to the evervarying conditions of the sea. The report on the pelagic Tunicata is of importance as the members of

- Commonwealth of Australia : Council for Scientiflc and Industrial Research. Bulletin No. 153: Pelagic Tunicates in the Plankton of Southeastern Australian Waters and their Place in Oceanographic Studies. By Dr. Harold Thompson; with a Statistical Analysis of Data on Total Plankton, by G. L. Kesteven. (Division of Fisheries, Report No. 8.) Pp. $56+1$ plate. Bulletin No. i57: Studies in the Biology of Australian Mullet, 1: Account of the Fishery and Preliminary Statement of the Biology of Mugil dobula Gunther. By G. I. Kesteven. (Division of Fisheries, Report No. 9.) Pp. $147+2$ plates. (Melbourne: Government Printer, 1942.) this group serve as indicators of changing oceanographical conditions which affect the course of the fishery.

This is the first report to be published on the investigations covering the period from May 1938 to January 1941, carried out by the motor vessel Wareen. During this period the whole south-east Australian area was repeatedly traversed, and oceanographical observations were made as frequently as they could be without interfering with the more specific fishery investigations. An intensive study has been made of the pelagic Tunicates which, except for Crustacea, form the chief portion of the zooplankton. The Tunicates are much more abundant in the subtropical and tropical waters than in the great fishery area of the colder portions of the northern hemisphere. No species typical of sub-antarctic (cold water) influences are found, those present being mainly circumtropical and sub-tropical.

Comparison of species and their relative numbers with those of other regions indicates a much closer affinity with south Japanese and Philippine and Indo-Malayan than with Californian conditions. Here there is a distinct probability that the pelagie fisheries of south-eastern Australia will develop on west- rather than on east-Pacific lines. From the unusually large number of rare circumtropical and sub-tropical species in $1939-40$ and from the simultaneous reduction in number of the more indigenous species, abnormally warm conditions apparently prevailed during that period, along with a progressive decline in the volume of plankton from 1939 onwards -conditions which adversely affected the fisheries.

The plankton, including the Tunicata; is much more concentrated in the upper 50-100-metre water layers than at greater depths, and several times more concentrated in the warmer than in the colder months of the year. Lesser and more uniform concentrations occur at greater depths. This affords some explana. tion of the surface shoaling of pelagic fishes and indicates that future investigations will yield most reliable results and be most economically pursued if chiefly inclined to the upper water layers in the warmer seasons of the year.

Of the pelagic salps of south-eastern Australia, Thalia democratica is by far the most characteristic, the next being Ihlea magelhanica, and thirdly Salpa fusiformis. Among the Copelata the outstanding species is Oikopleura longicaudata. The younger colonies of Pyrosoma atlantica are extremely abundant at times. A list of the species so far found in south. eastern Australian waters is given, but systematic and general data with keys to identification are reserved for a separate publication.

The study of the Australian mullet fishery relates chiefly to Mugil dobula, probably the most important of the inshore species. The result of the work shows there is undoubtedly over-fishing and that more restrictions should be placed upon the operatives of the industry in order that the stocks may be allowed to recover and possibly improve beyond earlier levels. A scheme for immediate and future action to secure restoration of the fishery is submitted.

The mullet fishery operates along almost the entire coast of Australia. There is a two-phase fishery of Mugil dobula which spends the greater part of the year in rivers and lakes and a few months in moving in truly marine water in shoals along the coast in spawning migrations. It is found by tagging experi. ments that the river and lake fish are not, as the fishermen supposed, distinct from those in the sea, 
but merely different phases of one life-history, the lake fish being slimy and dark and the sea fish clean and shining blue. On the east coast there is a continuous movement from the southern rivers into those north of them, and there must be recruitment from the north as there are apparently no separate races, and there is probably one intermingling stock. Thus the problem is one for a single uniform policy.

The mullet is $a$ bottom feeder and eats the sandy and muddy slime of the fresh and brackish waters, taking in the organic substances in it. Presumably, feeding ceases when the fish move to the sea. The larval development is unknown, but there are reasons to believe that the egg is pelagic and hatches within a short period, spawning probably occurring at or near the mouths of the estuaries in the surf zone. The young fish are still within a few miles of the estuary at the end of the first year, but after that they move farther up the rivers or lakes and spend their second and third year there.

\section{NEW ZEALAND EARTHQUAKES DURING 1941}

A CCORDING to the report on seismology for the year ended December 31, 1941, which has recently been received from the acting director, R. C. Hayes, the total number of earthquakes reported felt in New Zealand during 1941 was 107 , the smallest number in any year since 1928 (Dominion Observatory Bulletin No. R.27, extracted from the Annual Report of the Department of Scientific and Industrial Research, 1941-42, Dominion Observatory, Wellington, New Zealand). The earthquakes, in addition to being reported by numerous individuals as having been felt, were recorded by instruments as follow, the situation of the instrument being given first, and the type of instrument in parenthesis afterwards : Auckland (Milne-Shaw), Arapuni (Milne), Rotorua (Jaggar), Tuai (Wood-Anderson), New Plymouth (Wood-Anderson), Hastings (Jaggar), Bunnythorpe (Jaggar), Wellington Central Station (Galitzin-Wilip, Milne-Shaw, Wood-Anderson, Jones, Imamura), Takaka (Imamura), Greymouth (Jaggar), Christchurch (Galitzin three components, Wood-Anderson), and Monowai (Jaggar). Milne-Shaw seismograph No. 36 was installed at the Auckland Museum early in April. However, it was not until November that the necessary apparatus was obtained for maintaining accurate time. There was considerable delay in establishing a Wood-Anderson seismograph at Kaimata near Greymouth owing to the war, but some progress has been made. The public works officials at Rotorua have developed a method of obtaining records on blueprint paper instead of on smoked cardboard. The seismograph at Chatham Islands has been temporarily suspended owing to the War.

Of the 107 shocks in 1941,61 were felt in some part of the North Island and 55 in some part of the South Island. Nine were felt in both Islands. The maximum intensity reported felt was Rossi-Forel (R.F.) 8. Although the number of shocks felt was small, seismograph records indicate that minor activity was much the same as in previous years. Earthquakes were comparatively frequent in the far north-eastern part of the North Island and in the central districts ; and there was more activity than usual in Canterbury. On the other hand, most of
Hawke's Bay was comparatively free from earthquakes. Occasional shocks originated in the far southwest. The only two outstanding seismic events occurred early in the year. These were (1) a shock of $R . F .8$ orjginating near Taneatua, in the Bay of Plenty, on January 9 ; and (2) one of R.F. 6-7 near Lake Coleridge, in Canterbury, on February 7. The Taneatua shock was of very shallow origin, and in spite of the high intensity in the epicentral region the maximum radius of the 'felt' area did not exceed 70 miles. The Lake Coleridge shock was of normal depth and its 'felt' area was also small (maximum radius about 100 miles). After-shocks of the Lake Coleridge disturbance continued at intervals throughout the remainder of the year. Both these earthquakes were approximately 5 on the instrumental magnitude scale. Other shocks with $R . F$. intensity 6 or greater than 6 were: April 6d. 18h. $46 \cdot 8 \mathrm{~m}$. U.T. from Taumarunui and Hastings to Queenstown and Dunedin (6), May 29d. 11h. 17.1m. U.T. parts of southern Hawke's Bay $(6+)$, August 10d. 10h. 05.2m. U.T. Southland, parts of Otago (6), and September 24d. Ilh. 39.5m. U.T. Opotiki to Wanganui and Waipawa (6). Four further shocks had scale 5 or rather greater, and one had scale 3 intensity.

Two notable features of the 1941 results were: (1) a prevailing tendency for activity to be concentrated towards the north-western side of the general seismic region; and (2) the occurrence of shocks slightly deeper than normal in the submarine region between Taranaki and Nelson and beneath the northern part of the South Island. This has been confirmed by a recent revision of the earthquake records of previous years.

\section{NUTRITION IN RELATION TO BONE GROWTH AND THE NERVOUS SYSTEM}

$T$ HE problem had its origin in observations made in 1918, when an experimental study of rickets was in progress. Some of the animals developed severe inco-ordination of movement, independently of rickets, and the condition clearly involved a different etiological factor. The latter differentiation of the anti-rachitic vitamin from vitamin $A$ made it possible to show that the inco-ordination of movement in young animals was due to vitamin A deficiency.

Examination of the peripheral and central nervous system revealed widespread degeneration of afferent nerves (cranial and spinal) and ascending fibres in the central nervoús system. The interpretation of the results at this period was that vitamin $\mathrm{A}$ deficiency produced degenerative changes in most nerve cells of afferent and ascending nerves, but left those of the descending and efferent nerves intact. Here the position was left for some years, but the unsatisfactory nature of the explanation impelled a return to the investigation. Since the 8 th nerve was obviously particularly affected, serial sections of the labyrinthine capsules were studied. This examination led to the finding of abnormal bone growth in the internal auditory meatus, which was clearly press. ing on both divisions of the 8th nerve. A similar

* Substance of the Croonian Lecture delivered by Sir Edward Mellanby, K.C.B., F.R.S., before the Royal Society on July 15. 